University of Nebraska - Lincoln

DigitalCommons@University of Nebraska - Lincoln

2009

\title{
Not All Oak Gall Wasps Gall Oaks: The Description of DRYOCOSMUS RILEYPOKEI, a new, Apostate Species of Cynipini from California
}

\author{
Matthew L. Buffington \\ Smithsonian Institution, matt.buffington@ars.usda.gov \\ Shelah I. Morita \\ North Carolina State University
}

Follow this and additional works at: https://digitalcommons.unl.edu/systentomologyusda

Part of the Entomology Commons

Buffington, Matthew L. and Morita, Shelah I., "Not All Oak Gall Wasps Gall Oaks: The Description of DRYOCOSMUS RILEYPOKEI, a new, Apostate Species of Cynipini from California" (2009). USDA Systematic Entomology Laboratory. 64.

https://digitalcommons.unl.edu/systentomologyusda/64

This Article is brought to you for free and open access by the Entomology Collections, Miscellaneous at DigitalCommons@University of Nebraska - Lincoln. It has been accepted for inclusion in USDA Systematic Entomology Laboratory by an authorized administrator of DigitalCommons@University of Nebraska - Lincoln. 


\title{
NOT ALL OAK GALL WASPS GALL OAKS: THE DESCRIPTION OF DRYOCOSMUS RILEYPOKEI, A NEW, APOSTATE SPECIES OF CYNIPINI FROM CALIFORNIA
}

\author{
Matthew L. Buffington and Shelah I. Morita ${ }^{1}$
}

(MLB) Systematic Entomology Lab, USDA, \% NMNH, Smithsonian Institution, 10th \& Constitution Ave NW, P.O. Box 37012 MRC-168, Washington DC 20013, USA (tel: 202-382-1784 e-mail: matt.buffington@ars.usda.gov); (SIM) Department of Entomology, North Carolina State University, Campus Box 7613, 2301 Gardner Hall, Raleigh, NC 27695-7613, USA (e-mail: simorita@ncsu.edu)

Abstract. - Cynipini gall wasps (Hymenoptera: Cynipidae) are commonly known as oak gall wasps for their almost exclusive use of oak (Quercus spp.; Fagaceae) as their host plant. Previously, only three of the nearly 1,000 species of Cynipini have been recorded from hosts other than Quercus. These three are known from western chinquapin (Chrysolepis), chestnut (Castanea) and tan bark oak (Lithocarpus), all lineages of Fagaceae related to Quercus. Here we describe Dryocosmus rileypokei Morita \& Buffington, new species, a second species of cynipine which attacks Chrysolepis. Unlike the previously known gall wasp $D$. castanopsidis, which produces a medium-sized spherical external gall near the base of the staminate (male) flowers of Chrysolepis sempervirens, D. rileypokei attacks the same host acting as a nut galler. Dryocosmus rileypokei creates a gall within the mesocarp wall of the nut and appears to draw nutrients away from the developing seed. Later instar larvae and teneral adults were found within these internal galls. It appears that the adult wasp eventually chews an exit hole from these galleries. The evolution of host use in the three, non-oak galling Dryocosmus species is discussed.

Key Words: Dryocosmus, Chrysolepis, new species, gall wasp, predisperal seed predator

Gall wasps (Hymenoptera: Cynipidae) represent one of the largest radiations of gall inducing insects. With more than 1,300 species worldwide, it is second only to the gall midges (Diptera: Cecidomyiidae) in alpha-level diversity (Ronquist \& Liljeblad 2001, Ronquist 1999). Most of this diversity is from the familiar oak gall wasps $(\sim 1,000$ spp.; tribe Cynipini) found throughout the Holarctic and Neotropical regions and known for their almost exclusive association with Quercus

* Accepted by David R. Smith
(Ronquist and Liljeblad 2001, Melika and Abrahamson 2002, Melika 2006). Although there has been significant biological and taxonomic work on Cynipidae (Ronquist and Liljeblad 2001, Ronquist 1999), particularly in the Palearctic Region (Melika and Abrahamson 2002, Melika 2006), much taxonomic work is still needed in the Nearctic Region.

Host use within Cynipidae is phylogenetically conservative. Ronquist and Liljeblad (2001) estimated that around 20 host shifts have occurred between plant families across the 1,300 species of 
cynipids - about 0.01 major host shifts per speciation event. This observation is underscored by the fact that $98 \%$ of cynipid species have known host records (Ronquist \& Liljeblad 2001). The rate of host shifts is an order of magnitude lower than the average estimated rate of host shifts per speciation event in phytophagous insects in general $(0.1-0.2$ host shifts/speciation event, Mitter and Farrell 1991). If we look exclusively at Cynipini, the degree of conservation is even higher: of around 1,000 species, all restricted to Fagaceae, only four are on hosts other than Quercus spp. (Weld 1957, 1959; Melika 2006, this study). Stone and Schönrogge (2003) suggest that host choice remains conservative because gall induction, and ultimately, gall morphologies, are extended phenotypes of the gall inducer's genome. Hence, specialization in the genome necessitates specialization in host plant choice, resulting in an evolutionary canalization through time. Consequently, the high fidelity of oak wasps on their hosts has been proposed as a method for understanding oak phylogeny and visa versa (Abrahamson et al. 1998).

Shifts from galling to non-galling behavior in cynipines may be costly. Most plant feeding insects must endure and detoxify an onslaught of defensive plant-derived secondary compounds (e.g., alkaloids, nicotinoids), leading several authors to suggest that plant secondary compounds play a critical role in speciation in phytophagous insects (e.g., Mitter and Farrell 1991, Janz and Nylin 1998, Becerra and Venable 1999). A biological feature unique to gall inducers is that these insects are not exposed to defensive plant secondary compounds while feeding (Cornell 1983, Price et al. 1987). Ronquist and Liljeblad (2001) suggest that since cynipids are not exposed to these defensive compounds, other factors of their biology are responsible for host specialization, such as physiological constraints with respect to gall induction (plant tissue modification), longevity of host plants, larval and adult stages occurring on the same individual plant, and the location and timing of oviposition.

Here we describe a new species of Cynipini, which is not associated with Quercus and forms galls in mature reproductive tissue (the nut). This new species belongs in Dryocosmus Giraud, 1859 and is associated with Chrysolepis sempervirens (Kellogg) Hjelmq. (Fagaceae) from the southern Cascade Range of California. Unlike D. castanopsidis (Beutenmueller, 1917), which also attacks C. sempervirens by forming staminate flower galls (male flowers), this new species attacks the female reproductive tissues by galling within the mesocarp of the nut. Prior to this study, all non Quercus-associated species of Cynipini were assigned to Dryocosmus (two species) and Andricus Hartig, 1840 (one species). Andricus mendocinensis Weld is reported to gall Lithocarpus densiflorus (Hook. \& Arn.) Rehder (tanbark oak) (Weld, 1957) and is not dealt with here. Dryocosmus castanopsidis was recorded from both Chrysolepis chrysophylla (Douglas ex Hook.) A. DC. and $C$. sempervirens (chinquapin; referred to as Castanopsis sempervirens in Weld (1957)); Dryocosmus kuriphilus Yasumatsu, 1951, was recorded from Castanea spp. (chestnut) (Yasumatsu 1951) and has spread throughout the world as an agricultural pest (reviewed in Melika 2006). The biology of these species is summarized in Table 1.

\section{Materials And Methods}

Terminology. Cynipid morphological terminology follows that of Ronquist and Nordlander (1989), Fontal-Cazalla et al. (2002) and Buffington et al. (2007); cuticular surface terminology follows that of Harris (1979). With respect to gall terminology, we employ 'nut gall' 
Table 1. Summary of host use within Cynipini with a focus on non-Quercus hosts.

\begin{tabular}{|c|c|c|c|}
\hline Gall Wasp & Damage Type & Host (all Fagaceae) & Reference \\
\hline $\begin{array}{l}\text { Dryocosmus rileypokei } \\
\text { Morita and Buffington }\end{array}$ & Nut galler & Chrysolepis sempervirens & $\begin{array}{l}\text { Weld } 1957 \text { (referred } \\
\text { to as Castanopsis } \\
\text { sempervirens) }\end{array}$ \\
\hline $\begin{array}{l}\text { Dryocosmus castanopsidis } \\
\quad \text { (Beutmiller, 1917) }\end{array}$ & $\begin{array}{l}\text { Staminate flower } \\
\text { galler }\end{array}$ & $\begin{array}{l}\text { Chrysolepis chrysophylla } \\
\text { and Chrysolepis } \\
\text { sempervirens } \\
\text { (chinquapin) }\end{array}$ & $\begin{array}{l}\text { Weld } 1957 \text { (referred } \\
\text { to as Castanopsis } \\
\text { sempervirens) }\end{array}$ \\
\hline $\begin{array}{l}\text { Dryocosmus kuriphilus } \\
\text { Yasumatsu, } 1951\end{array}$ & Bud galler & $\begin{array}{l}\text { Castanea spp. (wild } \\
\text { chestnuts) }\end{array}$ & $\begin{array}{l}\text { Yasumatsu 1951; } \\
\text { reviewed in } \\
\text { Melika, } 2006\end{array}$ \\
\hline Other Dryocosumus (29 sp.) & Vegetative tissue galler & Quercus spp. & Weld 1957, 1959 \\
\hline Andricus mendocinensis Weld & Vegetative tissue galler & $\begin{array}{l}\text { Lithocarpus densiflorus } \\
\quad \text { (tanbark oak) }\end{array}$ & Weld 1957 \\
\hline $\begin{array}{l}\text { Callirhytis (14 sp.) } \\
\text { Eumaryia (1 sp.) } \\
\text { Loxaulus (1 sp.) } \\
\text { Andricus (1 sp.) }\end{array}$ & Acorn nut gallers & Quercus spp. & $\begin{array}{l}\text { Weld 1957, 1959, } \\
1960\end{array}$ \\
\hline $\begin{array}{l}\text { Callirhytis (5 sp.) } \\
\text { Andricus (2 sp.) } \\
\text { Eumaryia (1 sp.) } \\
\text { Neuroterus (1 sp.) } \\
\text { Amphibolips (3 sp.) }\end{array}$ & Acorn cap gallers & Quercus spp. & $\begin{array}{l}\text { Weld 1957, 1959, } \\
1960\end{array}$ \\
\hline Other Andricus (427 sp.) & $\begin{array}{l}\text { Vegetative tissue } \\
\text { galler }\end{array}$ & Quercus spp. & Melika, 2006 \\
\hline Other Cynipini (1,066 sp.) & $\begin{array}{l}\text { Vegetative tissue } \\
\text { gallers }\end{array}$ & Quercus spp & $\begin{array}{l}\text { Weld 1957, 1959, } \\
\text { 1960; Melika, } \\
2006\end{array}$ \\
\hline
\end{tabular}

through this paper, as opposed to 'acorn gall' or 'stone gall'; these latter two terms are common in Weld (1957, 1959). Specifically, the term 'acorn' refers to the single, one seeded, fruit (nut) produced by plants in the genus Quercus. Other genera in the Fagaceae can have multiple nuts per cupule ( $\mathrm{Oh}$ and Manos 2008).

Rearing methods. The female inflorescence of Chrysolepis sempervirens consists of a spiny cupule (bracts), which contains three flowers. Each of these three flowers produces an acorn-like nut. Green bracts containing nuts were cut directly from several large, shrubby $C$. sempervirens just south of Lassen $\mathrm{Na}$ tional Park in Plumas County, CA, in early August, 2005 and early September, 2007. All samples were placed in plastic zipper bags for further processing in the lab. Adult wasps that emerged from plant material inside the plastic bags were aspirated and placed in 95\% ethanol. Bracts and nuts were dissected with a razor blade under a Leica Wild M10 stereomicroscope. Through the dissection of eleven nuts, we recovered one live larva, four dead, teneral adults, and nine excavated seed tests.

Descriptions. Specimens were examined using a Leica Wild M10 with fluorescent lighting. Images were obtained using an EntoVision Imaging Suite, which included a firewire JVC KY-75 3CCD digital camera mounted to a Leica M16 zoom lens via a Leica z-step microscope stand. This system fed image data to a desktop computer where Cartograph 5.6.0 (Microvision Instruments, France) was used to capture a fixed number of focal planes (based on 


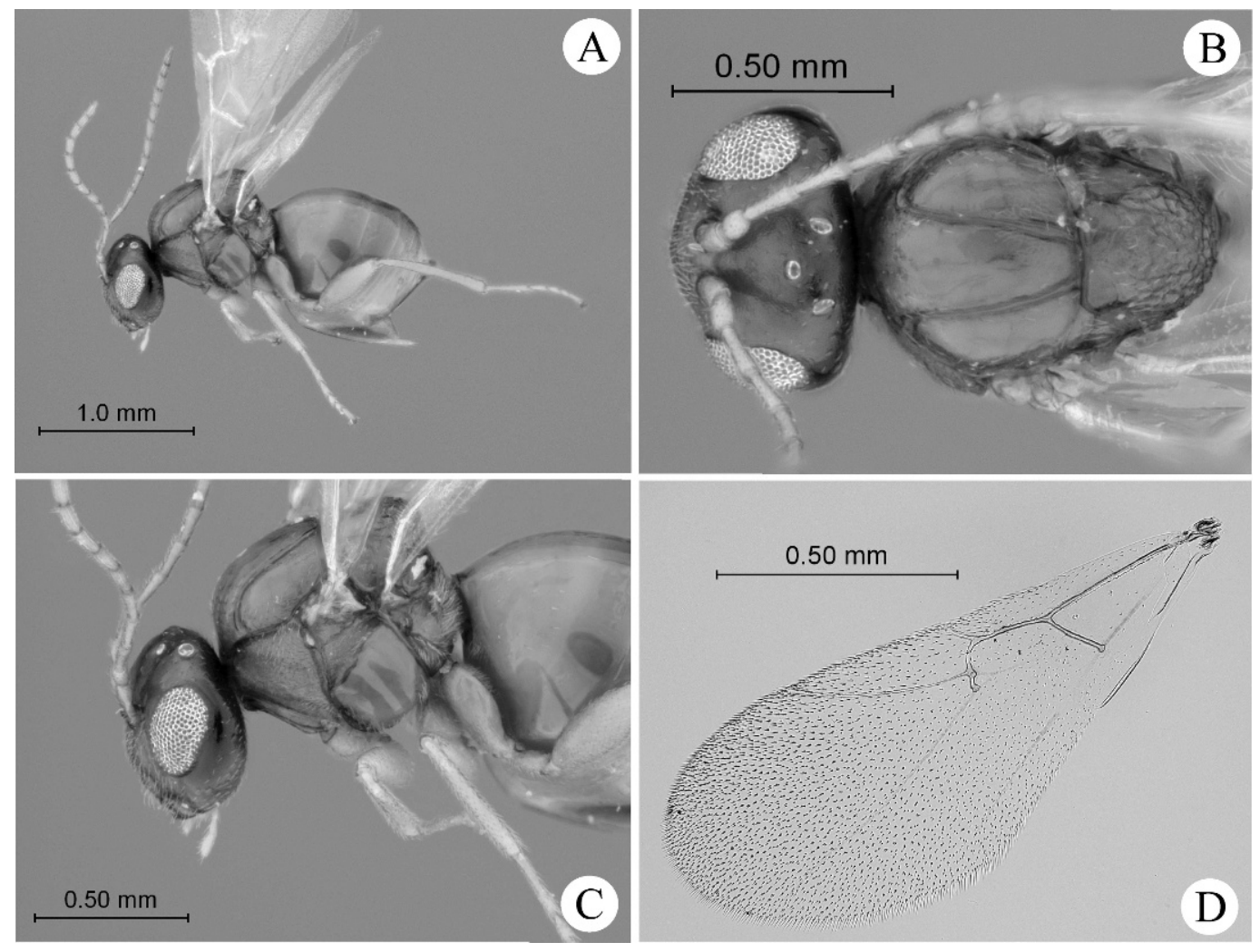

Fig. 1. Dryoscosmus rileypokei, female paratype (USNM). A, lateral habitus. B, dorsal head and mesosoma. C, close up, lateral head, mesosoma and anterior metasoma. D, left forewing, ventral view. Photos by MLB.

magnification); the resulting focal planes were merged into a single, in-focus composite image. Lighting was achieved using an LED illumination dome with all four quadrants set to $99.6 \%$ intensity. Images of this species can be obtained from www.morphbank.com, collection ID number 195584. All specimens examined are deposited in the National Museum of Natural History, Smithsonian Institution, Washington, DC (USNM).

\section{Dryocosmus rileypokei Morita \& Buffington, new species}

(Figs. 1, 2)

Diagnosis.-Distinguished from all other Drycosomus by the completely smooth mesopleuron (at least partially striate or shagreened in all other species) and by its galling nuts on Chrysolepis sempervirens. Distinguished from the non-Quercus associated species, such as D. kuriphilus, by the presence of distinct, smooth, scutellar pits (triangular and ribbed in D. kuriphilus), by the lack of a central propodeal carina (distinct central carina present between propodeal carinae in D. kuriphilus) and by the host plant being Chrysolepis sempervirens (Castanea spp. in D. kuriphilus); from D. castanopsidis by the lack of a median mesoscutal impression (at most a notch) (present in D. castanopsidis, often extending to $1 / 5$ the length of the mesoscutum) and by being a nut galler ( $D$. castanopsidis produces a spherical exter- 


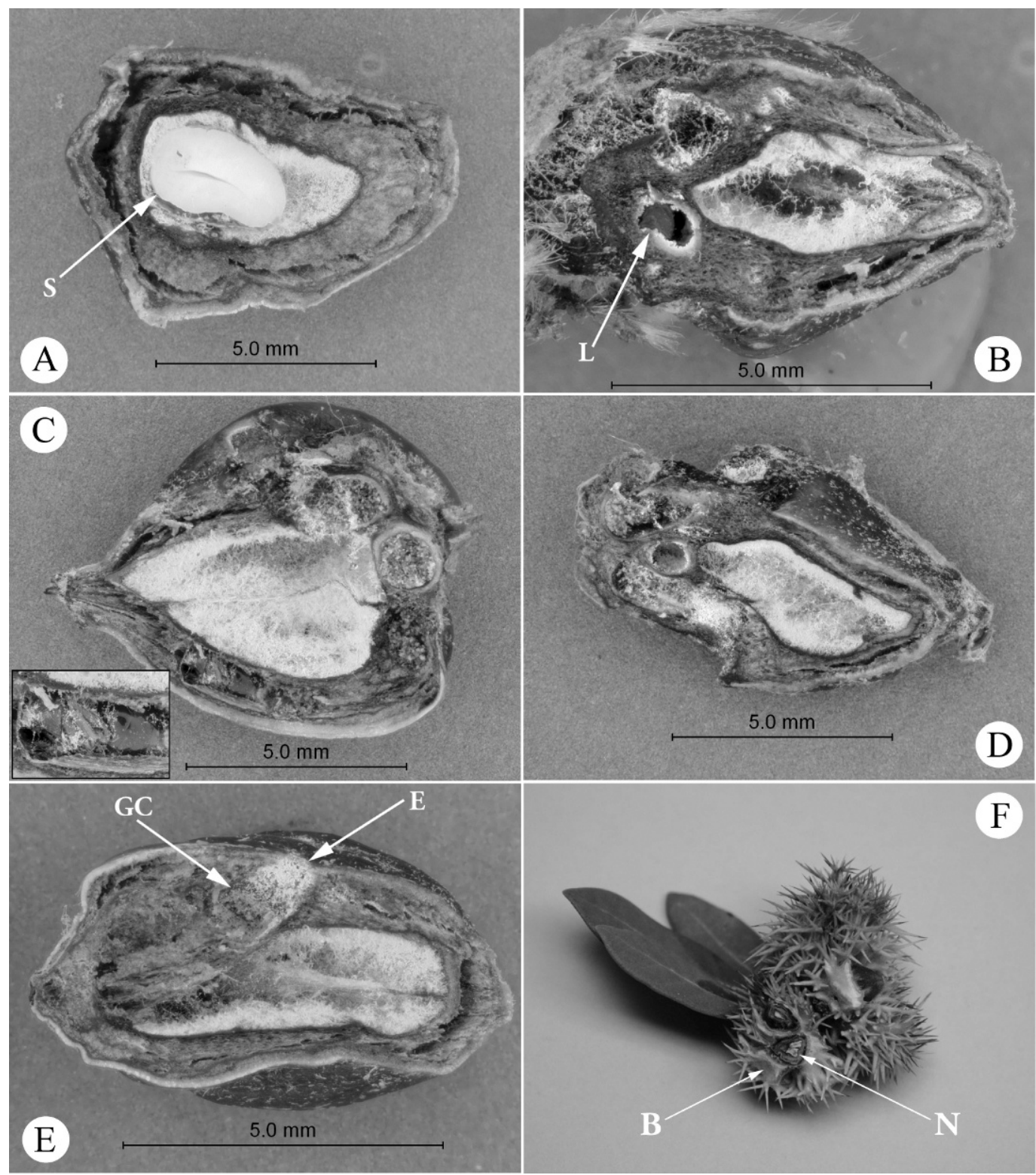

Fig. 2. Galls of Dryoscosmus rileypokei from Chrysolepis sempervirens. A, cross-section of undamaged nut; white mass in middle is the endosperm $(\mathrm{S})$. B, damaged nut; $\mathrm{L}=$ larva (small white shadowy structure); note seed is reduced in size when compared to Fig. 2A. C, damaged nut with trapped adult D. rileypokei (inset is a zoom of the wasp). D, damaged nut that resulted in successful emergence of adult; note gall chamber occupies the entire left $1 / 3$ (basal third) of the nut. E, damaged nut showing the gall chamber (GC) and exit hole (E). F, nuts (N) and bracts (B) of Chrysolepis sempervirens prior to dissection. Photos by MLB.

nal gall at the base of the staminate (male) flowers of Chrysolepis sempervirens).

Description.-Adult female. Color (alive or freshly killed): head and meso- soma dark brown-orange, metasoma bright orange when alive; legs and antenna bright creamy yellow.

Head: Frons slightly rugulose, densely setose; clypeus protruding, pinched later- 
ally by clypeo-pleuralstomal line; short striae radiating from clypeo-pleuralstomal line dorsally towards ventral margin of eye, malar sulcus absent; gena and vertex gently shagreened, covered in sparse, short appressed setae (Fig. 1C); gena broadly rounded (Fig. 1C). Toruli deeply impressed into face with distinct trench present; antenna with 12 flagellomeres, non-clavate, F1-F3 $4 \times$ longer than wide, F4-F7 3-3.5 $\times$ longer than wide, F8-F12 $2 \times$ longer than wide; short appressed setae on all flagellomeres (Figs. 1A, C).

Mesosoma: Lateral surface of pronotum slightly rugulose, moderately covered in short appressed hairs (Fig. 1C); lateral pronotal carina lacking, pronotal plate narrow, submedial pronotal depressions deep, open laterally. Mesopleuron completely smooth and glabrous below mesopleural triangle (Figs. 1A, C); mesopleural triangle deeply impressed, setose, clearly defined along all edges (Figs. 1A, C). Mesoscutum completely smooth, glabrous, with sparse setae along anterior and lateral edges; anteroadmedian signum indistinct; median mesoscutal impression lacking; notauli complete, originating at anterior end of parascutal impression, very gradually widened posteriorly (Fig. 1B). Disk of scutellum deeply rugulose, entirely glabrous (Fig. 1B); scutellar ridge separating scutellar fovea narrow, short; scutellar fovea oval, obliquely angled relative to midline, posterior rim present, center smooth, glabrous (Fig. 1B).

Metapleural-propodeal complex: Metapleuron glabrous anterodorsally, gradually more setose posteroventrally (Fig. 1C); anterodorsal depression of metepisternum elongate, triangular, widened ventrally, setose, bordered posteriorly by distinct metapleural carina (Fig. 1C); upper episternum deeply excavated by spiracular groove (prespiracular area of Ronquist 1995), bounded posteriorly by calyptra; lower episternum smooth, glabrous; setal pit at ventral margin of metapleuron indistinct; posterior aspects of propodeum smooth to gently rugulose, flat, evenly covered with long white setae; propodeal carinae thin, complete, parallel; lateral propodeal carinae absent; area between propodeal carinae smooth; nucha short, glabrous, deeply rugulose.

Wings: Marginal cell elongate, open along anterior margin (Fig. 1D); areolate present; marginal, radial sector and cubital veins represented by trace veins; short setae present on wing surface and along margins.

Legs: Coxae glabrous except for dense, linear setal patches on anterior face; metacoxa with addition linear setal patch on posterior face; sparse, appressed setae present on all femorae and tibiae. Tarsomeres evenly covered in short, appressed setae; length of tarsomere 1 equal to combined length of tarsomeres 2-5; claw simple (without basal tooth).

Metasoma: Petiole obscured by anterior margin of tergum 3 (T3); all postpetiolar terga free; T3 $3 \times$ length of T4, exposed length of remaining terga that of T4; posterior margins of all metasomal terga parallel, gradually angled away from midline posteriorly; T4-T9 with extremely minute micropores; sparse setae present on T8; hypopygium (sternite 7) distinctly extended ventrally; sparse, elongate setae presently along extreme ventral margin.

Adult male. Unknown.

Description of nut damage.-Damage contained within nuts (c.f., Fig. 2F); lateral aspects of base of nut pericarp bulged slightly and mesocarp layer relatively thick when compared with undamaged nuts; larval chamber circular in cross-section and found within the mesocarp layer (GC, Fig. 2E; also visible in Figs. 2B-D; also see diagram, Fig. 3), seed (= endosperm and embryo; S, Fig. 2A) missing in infested nuts; exit hole of adult usually located near equator of nut, occasionally at base of nut. 


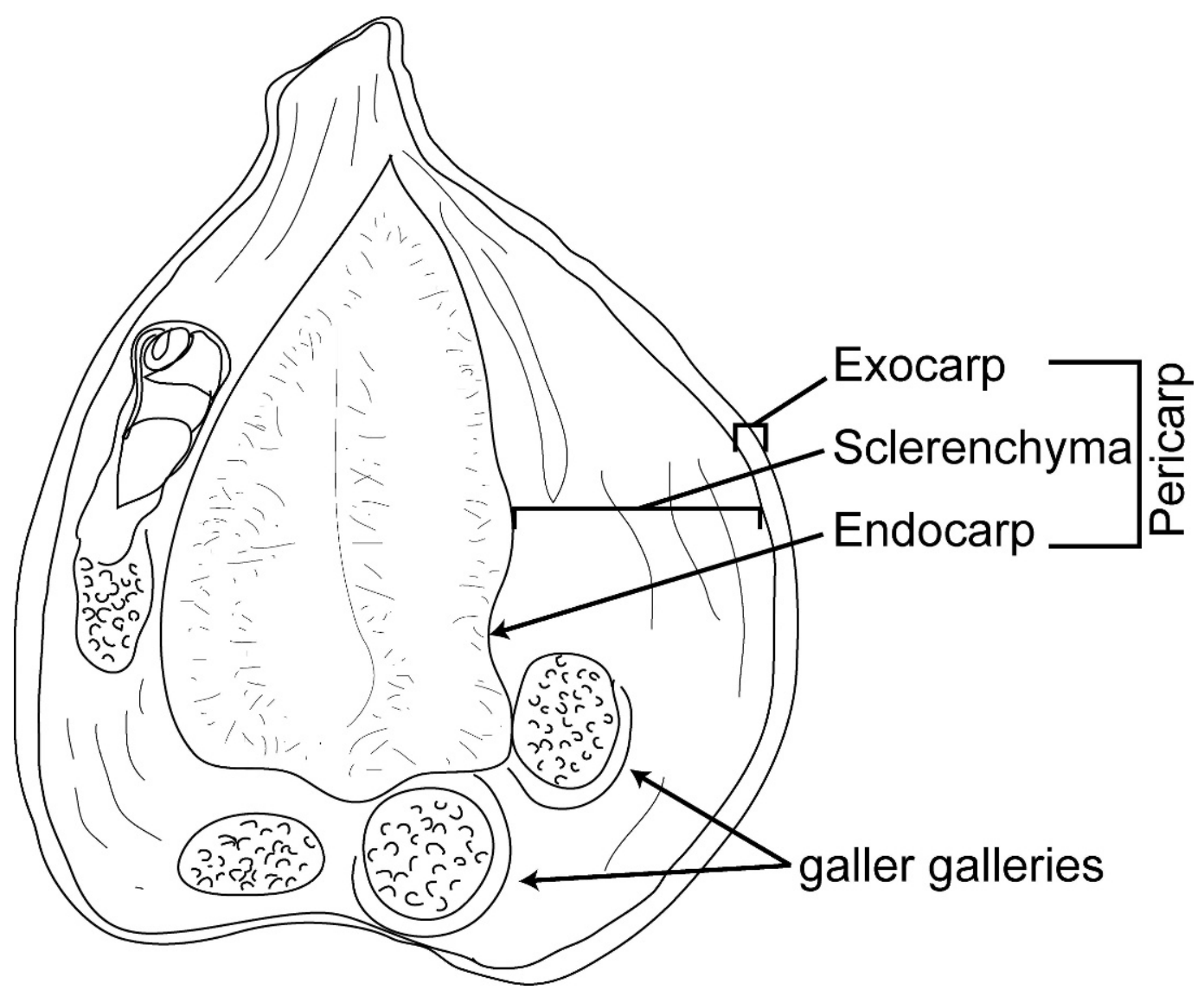

Fig. 3. Diagrammatic cross-section of $C$. sempervirens nut with damaged caused by D. rileypokei. Drawing by SIM.

Material examined.-Holotype. USA: CA, Plumas Co., Plumas Natl. For., $12 \mathrm{mi}$ north of Chester on Juniper $\mathrm{Lk}$ Rd., nut collected 8.VIII.2005, emergence date the same, Morita \& Buffington, coll., ex Chrysolepis sempervirens nut. A female in good condition; deposited in USNM. Paratypes. USA: CALIFORNIA. Plumas Co., Plumas Natl. For., 12 mi north of Chester on Juniper Lk Rd., nut collected 8.VIII.2005, emergence date the same, Morita \& Buffington, coll., ex Chrysolepis sempervirens nut (3 females, USNM); Plumas Co., Plumas Natl. For., $12 \mathrm{mi}$ north of Chester on Juniper Lk Rd., nut collected 6.IX.2007, emergence dates between 9.IX.2007-12.IX.2007, Buffington, coll., ex Chrysolepis sempervirens nut (5 females (one still in nut), USNM).

Image repository.-A collection of images of this species can be found at http://www.morphbank.com, collection ID number 195584.

Biology and distribution.-Dryocosmus rileypokei is set apart from other Cynipini as a nut galler on Chrysolepis sempervirens. In all $C$. sempervirens nuts examined, the gall is within the mesocarp layer of the lower one-half of the nut, expanding the walls of the nut slightly, resulting in a gentle bulge, and are presumed to have acquired nutritional resources normally sent to the developing seed. Emergence holes usually were located along the side of the nut 
(Fig. 2E) or at its base. In one nut examined, three adult wasps (dead) were removed, indicating that each nut can support more than one adult wasp. The distribution of this wasp is probably coincident with Chrysolepis sempervirens, which can be found throughout the Sierra Nevada and Cascade ranges of CA, NV, and southern OR (McMinn 1939).

Parasites.-One species of Eurytoma Illiger and one species of Sycophila Walker (Hymenoptera: Chalcidoidea: Eurytomidae) were reared from nuts of $C$. sempervirens containing $D$. rileypokei. However, the hosts for these two chalcidoids were not specifically isolated.

Etymology.-This species is named in honor of our field assistant, Riley Buffington (Newcastle Elementary), who was 'poked' several times by the sharp spines on the bracts of $C$. sempervirens. The name is masculine.

\section{Discussion}

The description of Dryocosmus rileypokei increases the number of cynipines reared from Chrysolepis to two species and the number of non-oak attacking species of Cynipini to four. Host use of these species and of other species within Cynipini is summarized in Table 1. Dryocosmus rileypokei is a remarkable species for two reasons. First, although this species is closely related to the Quercus gall makers (Nylander 2004, Liljeblad 2002), it attacks Chrysolepis, a close relative of Quercus (Manos et al. 2001). Currently, the ancestral host plant family for the clade Cynipini is uncertain due to ambiguous relationships both within Cynipini and between Cynipini and its probably sister taxa (Ronquist and Liljeblad 2001). The four apostate species of Cynipini discussed here ( $A n$ dricus mendocinensis, Dryocosmus castanopisidis, D. kuriphila, and D. rileypokei) may be remnants of a non-Quercus associated lineage of Cynipini now large- ly extinct. Alternatively, this observation may simply be an artifact of sampling bias, and many more species of nonQuercus associated Cynipini await discovery.

The second reason Dryocosmus rileypokei is remarkable is due to this species' behavior as a nut galler. According to Weld (1957, 1959), 12 of 443 species of Cynipini of North America are acorn nut gallers (all recorded from Quercus spp.). Either Cynipini nut gallers are rare, and/ or we have simply overlooked them. A hidden cost to galling nuts is the very fact that nuts are an important food source for many vertebrates, and this may help explain why nut gallers are naturally rare. On the other hand, galled nuts may have stunted development and not abscise from the plant to fall to the ground. This might allow them to escape nut predators. Overall, locating and rearing nut galling cynipids is difficult, and this has likely led to an underestimate of the true diversity of this niche (Ronquist, pers. comm.). Additionally, most gall wasp researchers collect galls and not seeds. If this is the case, it is likely that many more species of cynipoids are associated with the seeds of Fagaceae.

Alternatively, nut galling behavior may have some advantages. Two hypotheses as to why galling insects induce galls are 1) to escape natural enemies (the Enemy Hypothesis, Stone and Schönrogge 2003), and 2) to obtain and control nutrients from the host plant (the Nutrition Hypothesis, Stone and Schönrogge 2003). Both of these hypotheses are satisfied by nut galling behavior, with little modification of host plant morphology, although the plant resource allocation may still be affected. Firstly, the protective exocarp of the nut can provide defense against natural enemies (although two species of Chalcidoidea were reared from one Chrysolepis sample) and moisture loss. Secondly, the developing nuts normally draw a great 
deal nutrients from the vegetative portions of the plant, which the maturing larva can acquire for its own use without much host plant modification. Galling within nuts may allow galling insects more control over the greater resource allocation to reproductive tissue. There is evidence that oviposition in predispersal seed predating insects can influence resource allocation by manipulating the probability of fruit set (and therefore larval success) (Brody and Morita 2000).

One intriguing possibility that deserves more study is that Dryocosmus rileypokei may in fact be the alternate generation of D. castanopisidis. Heterogeny, or cyclical alternation between sexual and parthenogenic generations), is a well-known phenomenon within the Cynipini ( $\mathrm{Pu}-$ jade-Villar et al. 2001). It is also notable that $D$. castanopsisidis galls male flowers and $D$. rileypokei female reproductive tissue on the same plant. Fresh collections of both species, in which DNA comparisons can be made, will help us support or refute this hypothesis.

Wasp-oak relationships are conserved within species (Ronquist and Liljeblad 2001), but closely related wasps do not appear to attack closely related oak species in a pattern consistent with lineage tracking. This suggests that, although the divergence times for oaks and Cynipini are similar (Liljeblad et al. 2008), the associations we observe may be more recent. For example, Abrahamson et al. (1998) proposed the use of Cynipini classification and ecology to understand relationships among the taxonomically confusing Fagaceae. Recent work on the phylogeny of Fagaceae using new single copy nuclear genes (Oh and Manos 2008) is inconsistent with the relationships of Abrahamson et al. (1998). Although the largest divergence of oak gall wasps are associated only with Quercus (Quercus), the specificity of their host association does not appear to support a hypothesis of lineage tracking.
Ács et al. (2007) and Melika (2006) suggest two distinct lineages exist within Dryocosmus: a Palearctic lineage associated with Section Cerris oaks and a Nearctic lineage that mostly gall Section Lobatae oaks. Based on mitochondrial (COI, cytb) and ribosomal data (28S D2D5), Ács et al. (2007) suggested Dryocosmus may not be monophyletic; further taxon sampling will be required within Dryocosmus to test this hypothesis. Once the phylogenetic placement of Dryocosmus species that are not associated with Quercus are better understood, we may begin to understand the evolution of host plant choice and nut galling within Cynipini.

\section{ACKNOWLedgments}

Essential field assistance was provided by Chris Pagan (UC Davis), Theodore Buffington (Sierra Oaks Elementary, Sacramento, CA), Riley Buffington, and Stryker Buffington (Newcastle Elementary, Auburn CA). Michael Gates (Systematic Entomology Laboratory, Washington DC) played a critical role in the host plant identification of western chinquapin, guided MLB in the delicate art of gall dissection, and provided the identification of the Eurytomidae reared from the galls. Paul Manos (Duke University, Durham, NC) provided helpful insight into Fagaceae relationships. John Brown and Thomas Henry (Systematic Entomology Laboratory, Washington DC), Natasha Mehdiabadi (Smithsonian Institution, Washington, DC), Kathy Schick (Essig Museum, UC Berkeley) and an anonymous reviewer provided critical comments that improved this manuscript dramatically.

\section{Literature Cited}

Abrahamson, W. G., G. Melika, R. Scrafford, and G. Csóka. 1998. Gall-inducing insects provide insights into plant systematic relationships. American Journal of Botany 85: 1159-1165. 
Ács, Z., G. Melika, Zs. Pénzes, J. Pujade-Villar, and G. Stone. 2007. The phylogenetic relationships between Dryocosmus Chilaspis and allied genera of oak gallwasps (Hymenoptera: Cynipidae: Cynipini). Systematic Entomology 32: 70-80.

Becerra, J. X. and D. L. Venable. 1999. Macroevolution of insect-plant associations: the relevance of host biogeography to host affiliation. Proceedings of the National Academy of Sciences 96: 12626-12631.

Beutenmueller, W. 1917. Descriptions of new Cynipidae. Canadian Entomologist 49: 345-349.

Brody, A. K. and S. Morita. 2000. A positive association between oviposition and fruit set: female choice or manipulation? Oecologia 124: 418-425.

Buffington, M. L., J. A. A. Nylander, and J. Heraty. 2007. The phylogeny and evolution of Figitidae (Hymenoptera: Cynipoidea). Cladistics 23: 1-29.

Cornell, H. V. 1983. The secondary chemistry and complex morphology of galls formed by the Cynipinae (Hymenoptera): Why and how? American Midland Naturalist 110: 225-234.

Fontal-Cazalla, F. M., M. Buffington, G. Nordlander, J. Liljeblad, P. Ros-Farré, J. L. NievesAldrey, J. Pujade-Villar, and F. Ronquist. 2002. Phylogeny of the Eucoilinae (Hymenoptera: Cynipoidea: Figitidae). Cladistics 18: 154-199.

Giraud, J. E. 1859. Signalements de quelques espèces nouvelles de Cynipides et de leurs Galles. Verhandlungen des Zoologisch-Botanischen Veriens in Wien 9: 337-374.

Harris, R. 1979. A glossary of surface sculpturing. State of California, Department of Food and Agriculture, Occasional Papers in Entomology 28: $1-31$.

Hartig, T. 1840. Uver die Familie der Gallwespen. Zeitschrift für Entomologie 2: 176-209.

Janz, N. and S. Nylin. 1998. Butterflies and plants: a phylogenetic study. Evolution 52: 486-502.

Liljeblad, J. 2002. Phylogeny and evolution of gall wasps (Hymenoptera: Cynipidae). PhD Thesis, Department of Zoology, University of Stockholm, Stockholm. 90 pp.

Liljeblad, J., F. Ronquist, J. L. Nieves-Aldrey, F. M. Fontal-Cazalla, P. Ros-Farre, D. Gaitros, and J. Pujade-Villar. 2008. A fully webillustrated morphological phylogenetic study of relationships amond oak gall wasps and their closest relatives (Hymenoptera: Cynipidae). Zootaxa 1796: 1-73.
Manos, P., Z. K. Zhou, and C. Cannon. 2001. Systematics of Fagaceae: Phylogenetic tests of reproductive trait evolution. International Journal of Plant Science 162: 1361-1379.

McMinn, H. 1939. An Illustrated Manual of California Shrubs. University of California Press, Berkeley, Los Angeles, London. 663 pp.

Melika, G. 2006. Gall wasps of Ukraine. Vol. 1 \& 2. Vestnik Zoologiii, Journal of Schmalhausen Institute of Zoology Supplement 21: 1-644.

Melika, G. and W. G. Abrahamson. 2002. Review of the world genera of oak cynipid wasps (Hymenoptera: Cynipidae, Cynipini), pp. 150 190. In Melika, G. and Cs. Thuróczy, eds. Parasitic Wasps: Evolution, Systematics, Biodiversity and Biological Control. Agroinform, Budapest.

Mitter, C. and B. Farrell. 1991. Macroevolutionary aspects of insect-plant relationships, pp. 35-78. In Bearnays, E. A., ed. Insect Plant Interactions. CRC Press, Boca Raton, FL.

Nylander, J. A. A. 2004. Bayesian phylogenetics and the evolution of gall wasps. PhD Thesis. Acta Univesitatis Upsaliensis. Uppsala, Sweden.

Oh, S-H. and P. S. Manos. 2008. Phylogenetic analysis of CRABS CLAW sequences and implications for cupule evolution in Fagaceae. Taxon 57(2): 434-451.

Price, P. W., G. W. Fernandes, and G. L. Waring. 1987. Adaptive nature of insect galls. Environmental Entomology 16: 15-24.

Ronquist, F. 1995. Phylogeny and classification of the Liopteridae, an archaic group of cynipoid wasps (Hymenoptera). Entomologica Scandinavica Supplement 46: 1-74.

- 1999. Phylogeny, classification and evolution of the Cynipoidea. Zoologica Scripta 28: 139-164.

Ronquist, F. and J. Liljeblad. 2001. Evolution of the gall wasp-host plant association. Evolution 55: 2503-2522.

Ronquist, F. and G. Nordlander. 1989. Skeletal morphology of an archaic cynipoid (Hymenoptera: Ibaliidae). Entomologica Scandinavica Supplement 33: 1-60.

Stone, G. and K. Schönrogge. 2003. The adaptive significance of insect gall morphology. Trends in Ecology and Evolution 18: 512-522.

Weld, L. 1957. Cynipid Galls of the Pacific Slope. Privately printed, Ann Arbor, MI. 80 pp.

. 1959. Cynipid Galls of the Eastern United States. Privately printed, Ann Arbor, MI. $155 \mathrm{pp}$.

Yasumatsu, K. 1951. A new Dryocosmus injurious to chestnut trees in Japan. Mushi 22: 89-93. 